\title{
PENERAPAN MODEL DEMING MENGGUNAKAN PERANGKAT FISHBONE CAUSE AND EFFECT DIAGRAM UNTUK PENINGKATAN MUTU TENAGA GURU
}

\author{
Adhe Kusuma Pertiwi \\ Achmad Supriyanto \\ Agus Timan \\ Jurusan Manajemen Pendidikan Pascasarjana \\ Universitas Negeri Malang Jalan Semarang 5 Malang 65I45 \\ adhe4555@gmail.com
}

\begin{abstract}
Abstrak: Mutu menjadi tuntutan pendidikan masyarakat di era globalisasi. Suatu sekolah dapat dikatakan bermutu apabila mampu memberikan layanan prima ke peserta didik. Tujuan penelitian ini untuk mengetahui masalah penyelenggaraan pendidikan menggunakan fishbone diagram yang selanjutnya diselesaikan melalui model peningkatan mutu menurut Deming. Metode yang digunakan dalam penelitian ini ialah pendekatan kualitatif dengan teknik wawancara, observasi, dan dokumentasi. Hasil dari penelitian menunjukkan bahwa di TK Kalam Kudus Malang perlu melakukan peningkatan mutu guru untuk mengembangkan kualitas pembelajaran sekolah.
\end{abstract}

Kata Kunci: Pendidikan, Fishbone, Mutu

\begin{abstract}
Quality is a demand for public education in the era of globalization. A school can be said to be qualified if it is able to provide excellent service to students. The purpose of this study was to determine the problem of implementing education using fishbone diagrams which were subsequently resolved through a model of quality improvement according to Deming. The method used in this study is a qualitative approach with interview, observation, and documentation techniques. The results of the study show that in the Kalam Kudus Malang Kindergarten, it is necessary to improve the quality of teachers to develop the quality of school learning.
\end{abstract}

Keywords: Education, Fishbone, Quality

\section{PENDAHULUAN}

Perkembangan ilmu pengetahuan dan teknologi berpengaruh besar dalam kehidupan masyarakat. Tuntutan pendidikan berkualitas atau bermutu semakin meningkat seiring keinginan mendapat sumber daya manusia yang mempuni. Sekolah sebagai penyelenggara pendidikan dapat dinilai mutunya dari produk dan jasa pelayanan yang diberikan. Pendidikan bermutu dapat diperoleh melalui proses perubahan berkelanjutan. Sallis (2008: 52) menyatakan jika mutu adalah sesuatu yang absolut dan relatif. Mutu absolut diartikan sebagai mutu yang memiliki idealisme tinggi dan harus dicapai, selain itu memiliki sifat produk yang berstandar tinggi. Mutu dalam pendidikan berfokus kepada peserta didik yakni kebutuhan peserta didik berkaitan dengan input, output, dan proses pendidikan (Mulyasa, 20 I I). Konsep perbaikan mutu secara berkelanjutan lebih dikenal dengan Total Quality Management (TQM) atau Manajemen Mutu Terpadu.

Konsep TQM sendiri sebelum dimasukkan ke dalam dunia pendidikan, ialah suatu konsep yang berhasil meningkatkan mutu dalam dunia industri. Sudiyono (2004) mendefinisikan TQM sebagai suatu sistem komprehensif yang melibatkan seluruh komponen organisasi untuk melakukan perubahan untuk jangka panjang dan berkelanjutan dengan fokus terhadap layanan pelanggan. Peningkatan mutu sekolah perlu dilakukan step by step dengan perencanaan yang matang dan melibatkan seluruh warga sekolah serta stakeholders. Supriyanto 
(20/4) menjelaskan sesuatu dapat dinilai bermutu apabila memenuhi standar atau bahkan melampaui standar tersebut. Dalam konteks ini, peningkatan mutu dilakukan dengan menekan kesalahan sejak awal (zero defect) dengan proses secara terus menerus.

Sallis (2008: 202) menyebutkan bahwa fishbone diagram merupakan adalah suatu daftar visual yang disusun terstruktur untuk menggambarkan penyebab yang berpengaruh dalam proses dengan cara memisahkan dan menghubungkan satu sebab dengan penyebab lainnya. Setiap pengaruh akan diurut sesuai dengan penyebabnya, dan bertujuan untuk mengelompokkan beberapa sebab berdasarkan kategori. Proses pengidentifikasian dengan mencari akar penyebab yang berpengaruh dalam proses perbaikan dan peningkatan mutu dari indikator: (I) Manpower; (2) Methode; (3) Materials; (4) Machine; dan (5) Environment sebagai indikator yang digambarkan sebagai tulang kecil. Sedang pada tulang besarnya adalah hasil analisis akar masalah dari ke-5 indikator tersebut yang mana akar masalah (tulang besar yang menuju ke kepala) yang merupakan quality productivity. Penggunaan perangkat ini ketika sebuah lembaga perlu mengidentifikasi dan mencari penyebab masalah atau faktor yang dapat mengarahkan pada sebuah perbaikan dan peningkatan mutu. Diketahui faktor atau penyebab suatu masalah akan memudahkan sekolah untuk memperbaikinya.

TK Kalam Kudus Malang merupakan salah TK swasta di Kota Malang yang berada di bawah naungan Yayasan Kristiani Kalam Kudus. Sebagai salah satu TK swasta yang masih baru di perkotaan tentunya banyak pesaing TK senior lain yang telah melekat di hati masyarakat Kota Malang. TK Kalam Kudus Malang harus mampu membuktikan mutu yang dimiliki sekolahnya sehingga layak untuk disejajarkan dengan sekolah senior yang lain. Maka dari itu, perlu dilakukan analisis kendala atau masalah dalam penyelenggarakan pendidikan di sekolah selama ini sehingga dapat dilakukan perbaikan yang berdampak terhadap meningkatnya mutu sekolah. Analisis masalah dapat dilakukan melalui perangkat fishbone diagram untuk mengetahui masalah yang menjadi fokus atau akar dari permasalahan sekolah. Selanjutnya, proses penyelesaian masalah dapat dilakukan dengan menggunakan siklus Deming yakni Plan, Do, Check, Act (PDAC).

Penelitian ini bertujuan untuk mengetahui masalah penyelenggaraan pendidikan menggunakan fishbone diagram yang selanjutnya diselesaikan melalui model peningkatan mutu menurut Deming, dengan mendeskripsikan beberapa hal antara lain: (I) keadaan sekolah; (2) masalah di sekolah; (3) faktor pendukung program; dan (4) proses penyelesaian masalah.

\section{METODE}

Metode yang digunakan dalam penelitian tentang mutu ini menggunakan pendekatan kualitatif dengan teknik wawancara dengan kepala yayasan, kepala sekolah, dan guru di TK Kalam Kudus Malang. Selain itu, dilakukan pula studi dokumentasi dan observasi terhadap kegiatan di sekolah. Analisis data penelitian ini menggunakan teknik analisis deskriptif. Terdapat tiga kegiatan analisis yakni reduksi data, display data, dan verifikasi data.

\section{HASIL DAN PEMBAHASAN}

Berdasarkan hasil data yang diperoleh melalui pendekatan kualitatif diperoleh data bahwa TK Kalam Kudus Malang memiliki tenaga pendidik sebanyak 17 orang dengan jumlah peserta didik 200 anak. Dalam Peraturan Menteri Pendidikan dan Kebudayaan Republik Indonesia Nomor 137 Tahun 2014 Tentang Standar Nasional Pendidikan Anak Usia Dini telah menjelaskan bahwa rasio guru dan peserta didik dalam pelaksanaan pembelajaran usia 4-6 tahun ialah 1:15 yang berarti satu orang guru harus mengasuh maksimal 15 anak. Jumlah peserta didik 200 dengan guru 17 orang maka seorang guru mengasuh I3-I5 anak.

Tenaga pendidik tersebut terdiri dari I kepala sekolah dan 16 guru kelas. Kepala Sekolah TK Kalam Kudus Malang merupakan lulusan SI PGTK sedangkan untuk gurunya sendiri sebagian telah mengenyam pendidikan SI akan tetapi tidak pada jurusan PGTK ataupun 
PAUD, untuk sisanya ialah guru lulusan SMA/SMK sederajat. Peraturan Menteri Pendidikan Nasional (Permendiknas) Nomor 16 Tahun 2007 telah menyebutkan bahwa guru pada PAUD/TK/RA harus memiliki kualifikasi akademik pendidikan minimum diploma empat (D-IV) atau sarjana (SI) dalam bidang pendidikan anak usia dini atau psikologi yang diperoleh dari program studi yang terakreditasi. Keadaan tenaga guru di TK Kalam Kudus Malang masih banyak yang belum linier sehingga perlu disetarakan agar memiliki mutu pendidik yang berkualitas.

TK Kalam Kudus Malang terbagi menjadi dua tempat yakni di daerah Kasin dan Tidar. Posisi sekolah yang berada di dua tempat berdampak terhadap fasilitas yang berbeda antara keduanya. TK Kalam Kudus Kasin memiliki kolam renang sedangkan TK Kalam Kudus Tidar tidak memiliki sehingga ketika ada kegiatan ekstrakurikuler maupun event-event tertentu mereka harus berpindah begitu pula dengan gurunya.

TK Kalam Kudus Malang memiliki 4 rombel pada setiap sekolah baik di Kasin maupun Tidar, terdiri dari kelas AI, A2 dan BI, B4. Setiap kelas dilengkapi dengan LCD, TV, rak makan, dan dapur. Pembelajaran di sekolah menggunakan Kurikulum 2013 yang diintegrasikan dengan nilai-nilai Kristiani. Pemberian materi terhadap peserta didik sehari-hari dilakukan dengan moving class dan berdasarkan tema-tema sehingga memungkinkan peserta didik belajar di luar ruangan.

Sebagai sekolah swasta, TK Kalam Kudus Malang diperbolehkan untuk menarik biaya Satuan Pelaksanaan Pendidikan (SPP) kepada orang tua peserta didik. Besaran biaya SPP disesuaikan dengan penghasilan setiap orang tua, karena TK Kalam Kudus Malang menerapkan subsidi silang untuk membantu peserta didik yang kurang mampu. Selain itu, sekolah juga memiliki muatan lokal Bahasa Mandarin, muatan lokal ini diberikan karena mayoritas peserta didik di TK Kalam Kudus Malang merupakan keturunan Cina dengan adanya muatan lokal ini dimungkinkan untuk menarik perhatian orang tua dalam memberikan pendidikan kepada putraputrinya di TK Kalam Kudus Malang.

Program dan sarana prasana yang dimiliki TK Kalam Kudus Malang tidak menjamin keberlangsungan organisasi sehingga perlu peningkatan mutu secara terus menerus mengingat banyak pesaing TK swasta di Kota Malang. Penggunaan fishbone diagram memudahkan sekolah untuk mengetahui masalah mendesak yang perlu diselesaikan oleh sekolah berkaitan dengan mutu. Uraian di atas merupakan keadaan sekolah pada saat ini, jika dilihat secara garis besar yang menjadi masalah di TK Kalam Kudus Malang antara lain kemampuan guru, sarana dan prasarana, program sekolah, dan posisi sekolah. Jika masalah tersebut dipetakan lebih jauh menggunakan fishbone diagram maka didapatkan hasil bahwa faktor yang paling mendesak ialah kemampuan guru karena berdampak langsung terhadap kualitas lulusan. Guru dapat dikatakan sebagai salah satu bagian paling penting dalam proses pendidikan. Tanpa guru, adanya pendidikan hanya sebagai slogan dan pencitraan semata karena segala bentuk kebijakandalam sektor pendidikan ujung tombak keberhasilannya berada di tangan guru. Guru menjadi titik pusat awal dalam rangka pembangunan pendidikan (Bappenas, 20I5).

Setelah diketahui masalah utama penyelenggaraan pendidikan di TK Kalam Kudus Malang maka siklus Deming diterapkan sebagai proses penyelesaian masalah. Siklus ini dipilih karena peningkatan mutu merupakan suatu proses yang tidak dapat terjadi secara instan sehigga membutuhkan suatu siklus yang terus menerus. Pertama, langkah awal yang harus dilakukan sekolah ialah melakukan perencanaan (plan). Langkah ini sekolah wajib melakukan pendataan terhadap guru-guru yang masih belum sesuai dengan kualifikasi SNP. Kepala sekolah bersama pengurus yayasan berkoordinasi membentuk tim kecil yang bertanggung jawab atas peningkatan kemampuan guru. Selanjutnya, dilakukan analisis pembagian beban mengajar apabila guru diberikan tugas belajar. Setelah analisis selesai sekolah dapat merencanakan anggaran yang dibutuhkan untuk peningkatan kemampuan guru. 
Kedua, apabila perencanaan telah dilakukan secara matang dengan mempertimbangkan segala unsur yang terlibat baik materil maupun non materil sekolah melakukan survei terhadap lembaga pendidikan tinggi khususnya di Kota Malang untuk diajak bekerja sama dalam program peningkatan guru di TK Kalam Kudus Malang dan memberikan pengumuman kepada para guru bahwa akan ada programm peningkatan kemampuan.

Ketiga, setelah melakukan survei dan berhasil menemukan lembaga untuk diajak bekerja sama selanjutnya panitia kecil melaporkan hasil survei dan anggaran yang harus dikeluarkan dalam program ini kepada kepala sekolah dan ketua yayasan untuk mendapat persetujuan. Selain itu, tahap ini berguna sebagai untuk mengecek kembali kebutuhan dan kesiapan sekolah dalam melaksanakan program peningkatan kemampuan guru.

Keempat, jika laporan dari panitia kecil dirasa sudah cukup dan sesuai dengan tujuan program maka program peningkatan kemampuan guru mulai diterapkan.

\section{KESIMPULAN DAN SARAN}

Implementasi tools TQM yakni dengan fishbone diagram untuk menemukan masalah dan diselesaikan melalui siklus Deming untuk meningkatkan mutu guru di TK Kalam Kudus Malang berjalan dengan efektif. Berdasarkan fishbone diagram yang telat dibuat ditemukan bahwa yang menjadi masalah mendesak yang harus diselesaikan ialah tentang kemampuan guru karena berkaitan dengan mutu lulusan.

Peningkatan mutu guru di TK Kalam Kudus Malang membutuhkan kerja sama antara sekolah dan yayasan serta stakeholders. Pengiriman tenaga guru ke pendidikan tinggi tidak langsung dapat mengatasi masalah, perlu pelatihan secara terus menerus agar kemampuan gutu terus berkembang.

\section{DAFTAR RUJUKAN}

Bappenas. (20I5). Guru Merupakan Penentu Keberhasilan Pendidikan : Realitasnya Masih Banyak Sekolah kekurangan Guru. (Online), (https://www.kompasiana.com), diakses 23 April 2019.

Kemdikbud. (2007). Standar Kualifikasi Akademik dan Kompetensi Guru. (Online), (http://vervalsp.data.kemdikbud.go.id/prosespembelajaran/file/Permendiknas\%20No\% 2016\%20Tahun\%202007.pdf), diakses 23 April 2019.

Mulyasa, H. E. (20I I). Manajemen dan Kepemimpinan Kepala Sekolah. Jakarta: Bumi Aksara

Permendikbud. (2014). Standar Nasional Pendidikan Anak Usia Dini. (Online), (http://luk.staff.ugm.ac.id/atur/bsnp/Permendikbud I 37 20I4StandarNasionalPAUD.pdf), diakses 23 April 2019.

Sallis, E. (2008). Total Quality Management in Education, Manajemen Mutu Pendidikan. Yogyakarta: IRCiSoD.

Sudiyono. (2004). Manajemen Pendidikan Tinggi. Jakarta: Rineka Cipta. 